
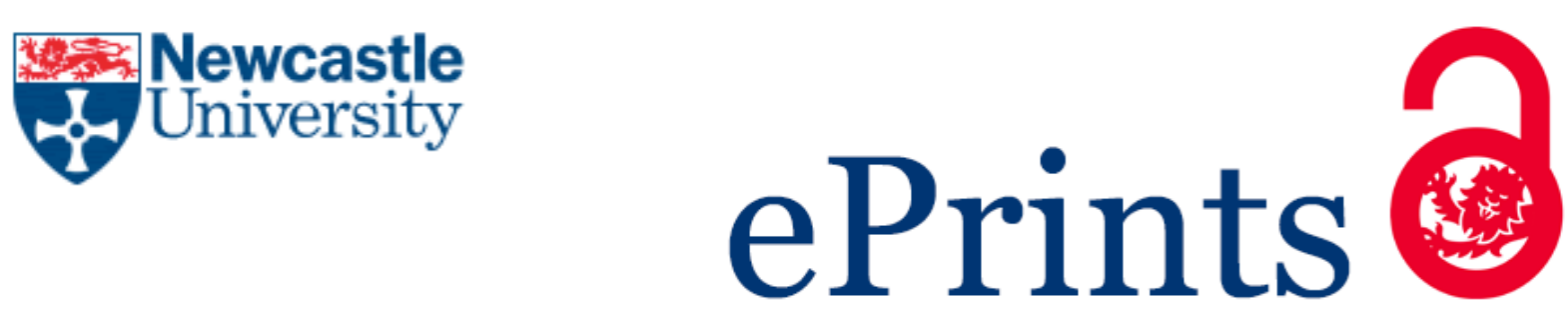

Laing K, Mazzoli-Smith L, Todd L.

The impact agenda and critical social research in education: hitting the target but missing the spot?

Policy Futures in Education 2017

DOI: https://doi.org/10.1177/1478210317742214

\title{
Copyright:
}

Copyright $@ 2017$ (The Authors). Reprinted by permission of SAGE Publications

DOI link to article:

https://doi.org/10.1177/1478210317742214

Date deposited:

$15 / 11 / 2017$

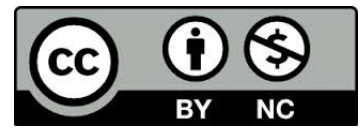

This work is licensed under a Creative Commons Attribution-NonCommercial 3.0 Unported License 
The impact agenda and critical social research in education: hitting the target but missing the spot?

\section{Karen Laing}

School of Education, Communication and Language Sciences, Newcastle University, UK

\section{Laura Mazzoli Smith}

School of Education, Communication and Language Sciences, Newcastle University, UK

\section{Liz Todd}

School of Education, Communication and Language Sciences, Newcastle University, UK

Corresponding author:

\section{Liz Todd}

School of Education, Communication and Language Sciences, King George VI Building

Newcastle University

Queen Victoria Road

Newcastle upon Tyne, NE1 7RU, UK

liz.todd@ncl.ac.uk

\section{Abstract}

This paper considers whether the impact agenda that has developed over the last decade in UK universities is likely to help create the conditions in which critical educational research makes a more visible difference to society. The UK audit of university research quality (the research assessment framework, REF) now includes an assessment of impact. Impact pathways are requirements of both national and EU research funding bodies and the Australian Research Council. Issues in the assessment of the social impact of research are explored by the European projects IMPACT-EV and ACCOMPLISSH. For many UK researchers the institutional focus on influencing the world outside the academy has brought welcomed support and resources to engage with society and may appear to bring universities back to something approaching their original civic identity. However, evidence from across the academy suggests that impact as depicted in REF impact case studies does not accurately represent the experience either of the academic research endeavor or of impact as it may be more broadly construed. Analysis reported here of 85 highly rated impact case studies in the education unit of assessment of the 2014 REF suggests there is a risk that the REF impact process will embed a shift against qualitative and theoretically driven methodology that is often found in socially critical educational research. Impact is postured as neutral, hiding the neoliberal drive towards research models based on implementation, 
evaluation and policy. There is a need to create spaces in universities for rethinking of the impact agenda, perhaps looking at value or social creation instead of, or as an integral aspect of, impact.

Key words

Impact, critical educational research, social justice, Bourdieu, valorization

\section{Introduction and context}

Analysis of the relationship between socially critical research in education and policy often leads to calls for action from the educational research community, such as to improve relevance or communication clarity (Francis 2011, Gardner 2011, Hillage et al. 1998). Given the increasing focus on impact and associated institutional support in many UK universities, one might expect that educational researchers are now able to make more difference to society. Our own experience as researchers was central to the motivation to write this paper. We have accessed and valued both the more strategic institutional approach to impact and the associated increased resource. However, we have at times found little congruence between the need to produce an impact case study (ICS) for the former and likely next REF and our efforts to make a difference to society. Policy influence that seemed to us highly valued in the 2014 research assessment framework (REF) is beyond our direct influence and the inspiring anecdotes that arise from long term relationships in the field are not those that would have counted as documentable evidence of impact in the context of the last REF. We wondered whether we, as critical educational researchers working in the area of social justice, would be able to make the difference that we ourselves valued, whilst at the same time finding currency in the next REF. The assessment of the social impact of research is of growing concern across Europe and is explored through two European projects, IMPACT-EV and ACCOMPLISSH. We were intrigued therefore that Colley looked at "What (a) to do about 'impact" (the title of her paper), and concluded that 'academics need to find collective ways to resist' the 'research 'impact' imperative' due to its encroachment on academic freedom' (Colley 2014, p660). It was in an effort to tease out our puzzlement, and find what we, and indeed the wider academic community could do about impact, that we wrote this paper. We build on Colley's arguments by looking at analyses of highly rated impact case studies from the 2014 REF from a range of subject areas including our own detailed analysis of those from the education unit of assessment. We extend Colley's use of Bourdieu's illusio to an understanding of the impact agenda in the light of our analysis. 
In terms of improving impact we suggest there is much evidence that educational researchers are on the case: they are constantly developing new ways to engage beyond the academy, including much use of social media (see blog of the British Educational Research Association ${ }^{1}$ ). Indeed, the relationship between critical educational research and policy or practice has always been complex, non-linear and contested and therefore always the focus of scrutiny as recognised by scholars internationally (Edwards 2002, Edwards 2000, Fine, Ayala and Zaal 2012, Lubienski, Scott and DeBray 2014, Mortimore 2000). Academics have contributed to the development of national policy for decades through a range of structures. This has included membership as long ago as the 70's of the 1978 Warnock committee of enquiry into 'Education of Handicapped Children and Young People', or the Schools Council abolished in 1984, or giving evidence to the $2016 / 17$ select committee in Education on such varied topics as mental health, grammar schools and multi-academy trusts ${ }^{2}$. At a more local and regional level academic research has contributed to the decision-making of schools, local authorities and related agencies though direct engagement as consultants delivering evaluations (Cummings, Dyson and Todd 2011, Mazzoli Smith and Todd 2016). Academics have influence by supporting the research of teachers themselves in many ways, such as through postgraduate training or initiatives such as Campaign for Learning's funded Learning to Learn (Hall et al. 2006) or the Oxford University education deanery supporting local school teachers' engagement in and with research ${ }^{3}$.

What has in the past been lacking for educational researchers has been the strategic support for impact from many universities. Research production is complex, one aspect being the institutional culture within universities and this has not always encouraged engagement with society. Such a situation is in contradiction with the origins of many UK universities in the $19^{\text {th }}$ century that was in response to the challenges of industrialization and urbanization. For example, Newcastle University has its roots in a School of Medicine in 1834 as a civic university, in response to the regional demands of an emerging industrial economy that included shipbuilding, mining, heavy engineering and agriculture. A civic focus was eroded over the twentieth century due to national agendas to prioritise research and teaching at a national rather than local level (and within this theory over practice) and

\footnotetext{
${ }^{1}$ https://www.bera.ac.uk/blog

2 http://www.parliament.uk/business/committees/committees-a-z/commons-select/educationcommittee/publications/

${ }^{3}$ http://www.educationdeanery.ox.ac.uk/
} 
national over local student recruitment (Goddard et al. 2016). Impact came to be understood in terms of reception within the academy (i.e. measured by journal citations). A more limited civic role remained in many universities, such as a commitment to professional training (i.e. medicine, engineering, architecture, teaching and a role to play in the regional development agencies in the enhancement of industry). Individual academics continued to sit on government commissions and committees and evaluate local authority provisions.

Although the $20^{\text {th }}$ century saw a detachment of universities from place, in the following decade universities reengaged with different versions of making a difference to society. The impact agenda as we now know it emerged in the late 2000's in response to national drivers to demonstrate the value of universities. Scholars note the 'engulfment of HE by neoliberal doctrine' (Chubb and Watermeyer 2016, p9) and associated structures of marketization, individualism, and competition with national and global league tables (Giroux 2002, Glenna, Shortall and Brandl 2015, Shore 2010). UK university funding started to be linked to an assessment of research impact that was added to the periodic national research audit (held roughly every five/six years). Impact is defined by REF guidelines as 'an effect on, change or benefit to the economy, society, culture, public policy or services, health, the environment or quality of life, beyond academia' generated by excellent research (HEFCE 2012 , p48). It accounted for $20 \%$ research income, at least $£ 1.6 \mathrm{~B}$ and has implications for university league tables. Excellence was graded in terms of 'reach' and 'scope'. The REF made a clear break with the previous focus on engagement by calling for evidence of impact that went beyond having civic society passively receiving research. Subject areas in universities were required to produce impact case studies (ICSs). These were 4-6 page documents that described research that was at least recognised internationally, and was carried out at the institution between 1993 and 2013 (for example see http://impact.ref.ac.uk/CaseStudies/CaseStudy.aspx?Id=26734). The case studies were to describe impacts that happened between 2008 and 2013, and for which up to ten pieces of evidence was provided, such as email testimony and the reference of research in policy documents. In addition to the REF, criteria for successful funding from the research councils evolved to require the demonstration of pathways to impact. This was prospective impact rather than the retrospective impact of the REF. The European policy for Responsible Research and Innovation emerged at the end of the first decade of the millennium, broadly concerned with Europe's ability to respond to societal challenges. RRI was a "re-evaluation of the concept of responsibility as a social ascription in the context of innovation as a future-oriented, uncertain, complex and collective endeavor" 
(Owen, Macnaghten and Stilgoe 2012, p757). The Framework Programme 7 EU funded project Impact-Ev focused on the development of indicators and standards for measuring impact, and generated debate about the imitations of dissemination in terms of achieving knowledge application, and transfer in terms of achieving improvement (Aiello and Joanpere, 2014). The ACCOMPLISSH project funded by the EU Horizon 2020 programme builds on the work of Inpact-Ev, by bringing together academics with representatives from industry, government and societal partners to develop an interdisciplinary co-creation approach to impact generation.

The role, scale and mission of higher education in the UK has evolved over the last few decades and is still evolving in relation to a myriad of national and global drivers including 'understanding of knowledge and modes of creation and dissemination, and societal and labour market requirements' (Goddard et al. 2016, p3). Many universities nationally and internationally are developing a range of institutional architectures for engaging with societal challenges that reflect in complex ways both neoliberalist influences and civic university origins (Ball 2012, Goddard 2009, Goddard and Vallance 2011, Goddard et al. 2016). What this means for individual disciplines or for socially critical educational researchers is not easy to predict.

\section{The impact of the impact agenda}

The 2014 REF produced over 6679 case studies of the impact of higher education research on society. Never before had there been an attempt on such a scale across the academy to assess its value to society. Given that impact will continue to play a key role in a future REF, analysis of this bank of case studies seemed crucial to consider the possible affordances of the impact agenda for the academic community. Kings College carried out a digital text mining and qualitative analysis of all 6679 non-redacted ICSs, suggesting a diverse and significant contribution of higher education research to society both in the UK and to all nations globally. There were, for example, 3709 unique pathways to impact. Interestingly small institutions made a disproportionate contribution (King's College London and Digital Science 2015). Here we review analyses of ICS research from a range of disciplines before discussing research examining ICSs from the education unit of assessment.

Analysis across the academy reveals an overall picture of the opening up of opportunities to make a difference that now have institutional support, but risks to the academic endeavor. A quote from the study of Edwards and Stamou (2017) of 13 social scientists all at one university, all successful at achieving impact, that took place just 
after claims for impact had been submitted to the national REF assessment, echoes some of our own sentiments: 'for others the demands allowed them to develop aspects of themselves as researchers that had long been important. "Yes it felt like a marginalised activity and now it's no longer marginalised, it's part of what everyone is trying to do. So for me it's a huge relief in terms of being allowed to do it publicly...it was a kind of undercover activity before."'(Edwards and Stamou 2017, p273)

Our own experience is that in recent years we have valued resources that have been made available from our own university for engagement and impact in terms of workload time, administrative support, funding for events and longer term projects, and capacity building events. Most notably we have valued the policy shift in our university to 'excellence with a purpose' accompanied by the development of a number of cross-university institutes focusing on societal challenge such as the Institute of Social Renewal. Smith and Stewart (2016) found similar views from interviews with individuals involved in research, policy and advocacy around health inequalities in the UK, undertaken between 2004 and 2015. Oancea's (2014) interviews with researchers from six case-study disciplines (from the social sciences, humanities and physical and engineering sciences) in one research-intensive university 'revealed ambiguities in researchers' takes on impact: while all of them were willing to articulate a clear sense of societal value at the heart of their work (and of universities' mission), this sense was broader and more fluid than the notion of impact underpinning current assessment processes'. Most researchers were found to be willing to engage with REF ICSs but found ICS preparation was onerous and time consuming (Marcella, Lockerbie and Bloice 2016), yet another administrative process (Knowles and Burrows 2014).

The main claim from this research into ICSs is that the impact depicted does not accurately represent the experience either of academic engagement or of impact as we would conceive of it in our everyday work and that this is potentially hazardous for the academy. Most analyses have highlighted the limits of linear, unidirectional, immediate and short-term conceptualisations of impact (Greenhalgh and Fahy 2015, Khazragui and Hudson 2015, Oancea 2014, Shortt et al. 2016). Khazragui and Hudson (2015) evaluated a number of REF case studies, and suggested that the use of commissioned research for case study impact might lead to less radical academic, less fundamental, research since initial ideas come from commissioners. The methodologies for capturing impact were found to often not fit in terms of validity or reliability expressed within a discipline 
such as clinical medicine (Ovseiko, Oancea and Buchan 2012). In the discipline of public health, Greenhaugh and Fahy (2015) analysed all 162 ICSs and asked the authors of four ICSs for narratives of impact efforts. The impact captured documented changed practice, guidelines and policy; in other words, was one step removed from patient outcome. Shortt et al (2016), also analysing public health ICSs, found little of the non-linear and nonimmediate nature of impact of social science research that is often referred to in the literature, such as demonstrated by work on alcohol and tobacco environments in Scotland. Shortt et al (2016) give the example of their own work on alcohol and tobacco environments in Scotland which sparked debates and conversations, such as national public radio debates, but did not operate in a linear manner in terms of having an impact.

The other main concern documented in research literature is that the research that leads more easily to the kinds of impact foregrounded in the REF does not reflect the full range of research from different subject areas and that this is likely to encourage certain kinds of research and inhibit others. Colley (2014), looking at education, suggests that the REF impact agenda has institutions encouraging researchers to focus on research reception rather than research production, with the danger that we might produce what receivers want to hear, rather than robust critical social science that might challenge the receivers. Her views are echoed by others (Fielding 2003, Knowles and Burrows 2014). Parker and von Teillingen (2012) have similar concerns in the area of social work research: "should the conceptual, theoretical and critical 'thorn-in-the-side' research be marginalised or disappear it is likely to make the research landscape less vibrant, anodyne and potentially much less useful" (p50). One of the few studies with contrasting findings is the content analysis of 25 of the 160 ICSs from 14 institutions submitted for the Library and information management Unit of Assessment. This study found the most common methodologies were consistent with those used more often in the discipline, theoretical work, literature review and qualitative interviews (Marcella, Lockerbie and Bloice 2016). On the other hand, Greenhaugh and Fahy (2015) in clinical medicine found qualitative and participatory research designs, common in the research outputs, were rare within ICSs. They also note that multi-stakeholder research collaborations such as UK National Institute for Health Research Collaborations for Leadership in Applied Health Research and Care are built on non-linear models of impact, which are not reflected in ICSs. Consequently we must examine whether the REF may encourage academics to work in linear ways that are more likely to lead to the evidencing of some kinds of impact, but which do not actually promote the most meaningful or effective models of impact. 
Some document the effect over time on a whole discipline, the discipline of anthropology, suggesting that "pure long-term field anthropology (is) being eroded for short-term commercial applications of anthropology "knowledge economy is reshaping anthropological research and popular understandings of ethnography" (Mills and Ratcliffe 2012, p147). Others suggest dangers for the academy as a whole. Chubb and Watermeyer (2016) interviewed 50 senior academics in the UK and Australia between 2011-15 in the arts and humanities, social science, natural and life science and physical sciences, from two research-intensive institutions. They concluded that "the hyper-competitiveness of the HE market is resulting in impact sensationalism and the corruption of academics as custodians of truth" (p4). The impact agenda is linked to the neoliberalisation of higher education by deepening "the self-marketization of the state through introducing new forms of competition in quasi markets, which enact and constitute the academic world and the ways in which we can live in it" (Shore and Wright 2000, p59). It therefore not surprising that for Colley (2014) the effect of forcing the REF version of impact on the academy is an encroachment on academic freedom.

\section{Analysis of high quality education impact case studies}

The dangers of the REF impact agenda for the academy have been consistently argued. However, ICSs did not skew the kinds of impact that are significant in all disciplines, as in the case of Library and information management (Marcella, Lockerbie and Bloice 2016). As researchers, it would be contrary to our values to make assumptions about the implications of the REF impact agenda for critical educational research. REF impact is here to stay, and our interest is in whether there is a way that it can be shaped so that critical educational research might make a more visible difference to society.

Our analysis comprised all ICSs that gained high REF ratings $\left(3^{*} / 4^{*}\right)$ for impact, in order to make inferences about the kind of impact that was valued in the REF process, and the kinds of research leading to such impact. To be eligible for the REF ICSs had to include research that was at least recognised internationally (i.e. outputs of at least $2^{*}$ quality) and carried out at the institution 1993 - 2013, and to describe impacts that happened 2008 2013. They then received an 'overall' grade for a university education group's ICSs and for their general impact strategy. Since ICSs were not graded separately, in order to include only those graded highly, we selected all the ICSs from universities that had received over $100 \%$ of its overall impact grade within $3^{*}$ or $4 *$. By making this 
selection we were not able to include any $3^{*} / 4^{*}$ ICSs where some of the overall impact grade was $2^{*}$ or $1^{*}$. It is therefore likely that there were other $3 * / 4 *$ ICSs that we excluded from our analysis that may have, had we included them, led to different conclusions. Similarly we omitted from our analysis any education ICSs that might have been presented in other units of assessment such as geography and sociology. 85 ICSs were identified and included in our analysis and these were from 21 universities: universities of Sheffield, Durham, Nottingham, Newcastle, Cardiff, Glasgow, Stirling, Belfast, Ulster, Manchester Metropolitan, Manchester, Loughborough, London Metropolitan, Edinburgh, York, Southampton, Institute of Education/University College London, Oxford, Bristol, Queen's, Kings College London. We made an exception to our criteria to include University College London/Institute of Education which curiously had $3.5 \%$ of its overall grade in $2^{*}$ and the rest in $3 * / 4^{*}$ as it seemed unlikely that this would apply to a whole ICS.

Drawing on the research literature quoted already in this paper of analyses of ICSs in other disciplines, we were interested both in the kinds of research that appeared in these ICSs, and the nature of the impact. A coding framework was produced with reference to this literature and to our own ICS on extended schools (appendix 1), and a read though of a sample of the 85 ICSs. The framework consisted of asking the following questions of the 85 ICSs in order to structure our analysis:

1. What kinds of impact are found: impacts directed to policy, professional practice or the lives and experience of children/young people/parents, or other? Linked to this, who are the main beneficiaries?

2. Does the impact have mainly a national or international reach or both?

3. What is the range of sources of evidence - and what trends can be identified?

4. On what kinds of research is impact claimed? Quantitative/ mixed methods/ qualitative/ theoretical?

5. Over what time period was the research carried out?

6. Was research carried out by a team or a sole researcher? Is there a clear lead researcher?

7. What links can be seen between the ICS and current UK education policy?

8. To what extent are 'negative' findings and impacts (e.g. which critique a current policy directive) included?

9. What other trends are observed? What questions occur? 
We made judgements about aspects that were not clear-cut, such as the type of research methods used, and we could only draw conclusion based on the information given in the text provided and the associated outputs. A subjective aspect to the analysis was impossible to avoid given the subjective nature of the terminology employed in the ICSs and the positive spin they necessarily adopt, as picked up by the King's College analysis (King's College London and Digital Science 2015, p7): 'While there was a large amount of numerical data included in the case studies, the way in which different numerical values were presented meant that the data could not be easily synthesized'. Nonetheless coding was carried out by one of the paper authors, and another carried out a moderation of the coding using a sample of $25 \%$ of the ICSs. This demonstrated a high level of coding agreement, with disagreements resolved through discussion. Where coding was problematic generated interesting issues such as in identifying impact that was counter to policy. This and other issues are discussed in the following section.

\section{What kind of impact and research was found in 85 education ICSs?}

Our first impression reading all 85 ICSs was of a vibrant, varied and highly influential national education research academy in the UK (at least from 2008-12), supporting the overall findings of the Kings' College research (King's College London and Digital Science 2015). Our judgement was supported by the REF panel report that "the case studies overall were extremely impressive" (Research Excellence Framework 2014)p111 Impacts included institutional changes, international policy and governmental shifts. Other impacts were profound, particularly in overseas contexts where academics held influential positions. Most focused on research that had been carried out for many years. For example, $25 \%$ resulted from research conducted for $20 y$ rs or more, $40 \%$ from research conducted between $11-20 y r s, 24 \%$ from research conducted between 6-10yrs, and less than 10 were conducted over a period of up to 5 yrs. Most (75\%) appeared to be a team effort and less than half seemed to have a clear individual named lead. $20 \%$ were with a small group of 2 or 3 researchers.

The main beneficiaries were policy makers, children, students, pupils, and practitioners but also NGOs, trades unions, families, the labour market, and to society as a whole. The reach of the research seemed to be national and international in most, but we judged that 13 had either mainly or only UK impact. The sources of evidence were varied and included web downloads, social media outputs, resource uptake percentage, workshop attendance, use of websites, quality marks, testimonies of policy and practice change. There were also awards 
included in the evidence, that were largely from within the academic community. This suggests internal selfvalidation that we may question as being legitimate sources of evidence of such ICSs.

Pathways to impact and intentional strategies that led to impact were not referred to in many ICSs, so judgements about these were not easy to make. The main mechanisms by which impact happened were reports or briefings, training materials, but also workshops, online toolkits, products to buy, and national standards. However, our own experience of compiling what became a $3 * / 4 *$ ICS (appendix 1 ) was the importance of a combination of serendipity and strategic endurance: working on the same area of research and engaging with partners over a long period of time, carrying out research on government policy that was also funded by the government, and engaging with stakeholders that put additional resource into engagement.

Most ICSs drew on mixed methods research, with many using solely quantitative methods and most having the model of initiative design and/or implementation and/or evaluation, leading to improvements to attainment, or influence on policy or curriculum. It was notable that very few ICSs were based solely on qualitative research. There seemed to be only one that was a solely theoretical analysis, but more that combined a conceptual analysis or theory driven approach with other methods.

We classified the ICSs in terms of impact on policy, practice and behaviour, our analysis necessarily making a judgement call based on what was presented in the ICSs in terms of how far behaviour is impacted. In only six was policy impact absent. In some, behavioural change was independently verified through an evaluation, but more common was secondary endorsement of behavioural change through stakeholder practice change or feedback. This leads to a number of questions. How is the value of independently verified behavioural change versus secondary endorsement of behavioural change assessed? There were many examples where the stated aim to improve attainment was not documented, only the prior step of changing practitioner behavior or practice. Policy impacts which were causal and discrete (e.g. a policy change or new practice) were easier to evidence than changes in pupil behaviours. Occasionally a discrete causal link was provided in the ICS using quantitative data reported in outputs. 
It was rare for impact to constitute a 'critique' of current education policy in the UK. However, this was not a simple judgement for us to make as researchers, since the development of policy might implicitly constitute a critique at some level. Large numbers of ICSs fell in current high profile areas in the field of educational research, which included assessment, school effectiveness, STEM subjects, early years and 'closing the gap' in attainment between rich and poor. We estimated that congruence or alignment with current educational policy could be identified for all but five ICSs, and for these the ICSs ran counter to current policy. However impacts which ran counter to current policy were mentioned by HEFCE, who:

"encouraged submissions of impact relating to the prevention of undesirable outcomes, acknowledging that research in the social sciences may hold authorities to account and result in a proposed change not taking place. The sub-panels welcomed the submission of such case studies and it is noteworthy that they were able to evidence impact and achieve the highest quality scores." (HEFCE 2015, p19)

Where research has been counter to prevailing policy, it has not necessarily been problematic for the generation of impact. For instance the researchers who critiqued the valued added measure and PISA scores for England were both used by the coalition government, being invited to do further research. Likewise the Oxford ICS on the SKOPE skills-training research reports a senior civil servant as saying the SKOPE research provided:

"the leading British critique of approaches to skills policy" and "an important oversight and challenge role by advocating alternative positions" [Section 5: C1]. Their report went on to state that "English policy makers valued the work of SKOPE as a type of "unofficial" opposition and their research is widely acknowledged to have provided material to fill important gaps in the skills evidence base."

\section{Discussion}

Most education ICSs could be construed as instrumental in producing more efficient or higher-quality and effective educational practices in line with extant educational policies. We would claim that impact is more readily demonstrated in this way. The legacy is not only these improved processes and practices, but also new methodological and analytical tools and instruments which are more likely to be taken up and utilised. However, there was much less emphasis on a legacy of critical or theoretical work as presumably impact is less immediate and tangible. This leads to the question of where this leaves the socially critical educational research that is 
largely sociological and often theoretical. Will the lack of readily accessible evidence of impact devalue such research, at least within the discourses of impact? The REF impact assessment process could be read, with few exceptions, in terms of the embedding of a shift towards 'robust,' 'evidence-based' and large-scale mixed or quantitative research with tangible evidence of impact in visible ways, and away from qualitative or theoretically driven work that may be more concerned with impacts at the socio-cultural level and over the longer-term. There are dangers too for socially critical educational research that is counter to prevailing practice or policy. Although we found a small number of ICSs that had evidence or such impacts, it is difficult to see how producing these will ever be anything other than more difficult within the current framework, as was the experience of Colley (2014).

That some kinds of impact are inherently easier to evidence than others needs addressing, or there will be an inevitable turn towards this kind of research in the allocation of funds given the RCUK focus on pathways to impact. It is also interesting to wonder about internal inconsistencies in the REF process itself. We are interested in how it is possible for the REF to accept ICS claims of change (of behavior, attainment etc.) when the quality of such judgements inevitably fall short of the rigour of sophisticated analysis that is required in research papers discussing similar changes in $3 * / 4$ educational research outputs.

Colley (2014) draws on Bordieu's neglected concept 'illusio' that 'calls us to examine the 'stakes' that matter in the field of educational research. The REF is a bureaucratic system that has changed the stakes of educational research whilst 'avowing disinterest through claims that the 'impact' agenda is solely acting for the public good (i.e. value for money use of public funds for research)" (p674-5). Bourdieu writes that "illusio is the face of being caught up in and by the game, of believing the game is "worth the candle", or more simply that playing is worth the effort.... It is to recognize the game and to recognize its stakes" (Bourdieu 1998, p76-77). Colley describes illusio as our 'investment in the game' (p669), what matters for us in conducting educational research, and suggests this is rendered illegitimate when one does not play according to the high stakes rules of the REF, i.e. by producing theoretical or qualitative critical research. Writing about illusio in respect of neoliberalism, Rowlands and Rawolle $(2013$, p269) say 'we are both playing the neoliberal game and inadvertently demonstrating our belief that it is a game that is worth being played'. This analysis in terms of illusio is helpful with respect to the impact agenda also. 
We suggest that impact, positioned as neutral and for the public good, in practice furthers a very specific neoliberalist ideology which has been much written about in higher education (Mudge 2008) We take heed of the concerns of Rowlands and Rawolle (2013) who argue that the undefined, generalist application of the term neoliberalism can further entrench its discursive hegemony rather than disrupt it. Our solution is to demonstrate, as we are doing in this paper, the linkage between the particular criteria and possible ramifications for research of the REF impact process, and a neoliberal turn in higher education, seen in concepts such as the knowledge economy, where cost-benefit logic informs, at least in part, how research funding is apportioned. This logic is dependent on quantifiable and evidencable impact and hence the particular shaping of the impact agenda to date.

There are other stakes in the broad impact agenda, other illusio, than that of REF ICS impact. Brewer (2013) talks about the value of the social sciences, referring to the way that an education in the social sciences enhances the life of a student, and also the way that social science reveals evidence about society and how society needs to adapt to deal with the complex problems of the $21^{\text {st }}$ century. We would advocate remembering that one of the most significant contributions of the impact agenda to universities has been the development of ideas about what a civic university can be and its role in the agendas of today. Internationally we have improved understanding of the role of academics in society (Aiello and Joanpere 2014, Brewer 2013, Shucksmith 2016), of the history of the civic university and its expression globally (Goddard and Vallance 2011, Goddard et al. 2012, Goddard et al. 2016).

'Many universities see themselves as anchor institutions within their local community, working with local and regional partners to promote economic, social and cultural regeneration. In the past social mobility has been analysed at national or individual institutional level with response tending to follow these polarities. However, increasingly the focus is on regional responses, with universities working with partners in their regions to develop sustained initiatives that align with broader agendas'. P24, para 56

Universities UK. 2016. "Working in Partnership. The Final Report of the Social Mobility Advisory Group" London: Universities UK. 
http://www.universitiesuk.ac.uk/policy-and-analysis/reports/Pages/working-in-partnership-enabling-

social-mobility-in-higher-education.aspx

Brewer advocates that we are not scared of making a difference since social science is a public good in its own right. He suggests we indeed change how impact is evidenced, widen discussion of the social sciences and talk of value not impact (Brewer 2013). Scholars involved in the European project IMPACT-EV add dissemination, transfer and social creation to impact in their discussion of the concepts that they suggest inform and demonstrate the degree of researchers' involvement in a scientific project and the improvements that this generates in society (Aiello and Joanpere 2014). Social creation involves the creation of new social realities by combining both scientific knowledge and a communicative praxis from the involvement of grassroots community members. ACCOMPLISSH is exploring the use of open innovation where civil society joins with business, universities and government sectors to drive change.

There is appetite for change from academics themselves. Oancea (2013a, p248) found that 'academics saw in the current context an important opportunity to debate and reconceptualise 'impact' and its relevance to accountability processes, and to re-calibrate assessment methodologies' from her research of accounts of interpretations and practices of research impact in six case-study disciplines (from the social sciences, humanities and physical and engineering sciences) in one research-intensive university. Colley (2014) quotes Delamont (2011) on the need for researchers to claim their own understandings of and values about impact. Shortt (2016) quoting Weiss (Weiss 1977) suggests an 'enlightenment' model that would "involve recognising that our research is just one small part of wider understandings and whilst we can contribute to change, this often takes time and research may not represent the defining determinant of change". She suggests "we should reward academics and departments that engage with external partners, the general public and interested parties, but we should not expect that all of this will lead to demonstrable change in the short to medium term" and we should alter the focus of REF impact from:

'demonstrable impact to demonstrable knowledge exchange and public engagement. It might also involve, for example, doing more to reward researchers (or knowledge brokers) who undertake synthesising type roles, collating and reviewing large disparate bodies of academic knowledge for non- 
academic audiences (as opposed to the current approach which largely encourages researchers to try to achieve impact for their own research). Such a focus would include more nuanced metrics of participation, involvement and action rather than 'change'.' (Shortt et al. 2016, p271).

We draw some hope for change from the REF itself. We note, and it is perhaps ironic that this is about an ICS from Oxford on research assessment, the influence of critical research on the panel assessing the REF ICSS,

'We made use of the report in agreeing on assessment judgements in the areas of environment and esteem as well as in assessing outputs. Thus the publication made a significant difference to assessment judgements, including encouraging the agreement to a different set of values from that used in 2001 in order to give greater respect to applied research. These judgements in turn of course affected research funding of education departments from 2009 onwards, favouring those with a greater proportion of applied research rather more than previously'. (Chair of the 2008 RAE sub-panel).

We also draw encouragement from the high value given to an ICS from UCL Institute of Education in which Stephen Ball's awareness is stated of the irony of his work on performativity being used in a REF ICS.

We conclude by drawing on Oancea once more, with thanks for the title of our paper from the final sentence of this

quote

(2013a, p248, 2013b, p7):

"For impact indicators to be an adequate proxy of research value, they need not only to be technically refined, valid measures, but also to be pitched at the right level, so that they can function as catalysts of higher education activity rather than destabilising it. To do this, they depend on a healthy ecology of higher education, which in turn requires intellectual autonomy, open debate, financial sustainability and insightful governance. Without these preconditions, the high-stakes assessment of impact might fail to reflect and support ongoing research value, and end up simply capturing assessment-driven hyperactivity: in other words, it might end up hitting the target, but missing the point." Oancea (2013a, 
p248, 2013b, p7).

We would want to emphasise that this 'healthy ecology of higher education' is also predicated on an understanding of whether and how current impact indictors and REF criteria foreground - and hence may foster - certain kinds of research at the expense of other kinds. This may appear as an instrumental - theoretical divide, but it is likely also be more complex in the case of critical social research in education as a result of its critical stance to much education policy. We would question how far therefore the impact discourse as it is currently configured in the REF can and should take us. We hope through this level of scrutiny of the impact agenda to support the debate about what might count as impact in the next REF. We would also espouse research value as being about value to society certainly, but understood in relation to our own value-orientations with respect to an ethically situated field of educational research.

Aiello, E and Joanpere, M (2014) Social Creation. A New Concept for Social Sciences and Humanities. International and Multidisciplinary Journal of Social Sciences 3(3):297313.

Ball, SJ (2012) Performativity, Commodification and Commitment: An I-Spy Guide to the Neoliberal University. British Journal of Educational Studies 60(1):17-28.

Bourdieu, P (1998) Practical Reason: On the Theory of Action. Stanford California: Stanford University Press.

Brewer, JD (2013) The Public Value of the Social Sciences: An Interpretive Essay. London: Bloomsbury.

Chubb, J and Watermeyer, R (2016) Artifice or Integrity in the Marketization of Research Impact? Investigating the Moral Economy of (Pathways to) Impact Statements within Research Funding Proposals in the Uk and Australia. Studies in Higher Education:113.

Colley, H (2014) What (a) to Do About 'Impact': A Bourdieusian Critique. British Educational Research Journal 40(4):660-681.

Cummings, C, Dyson, A and Todd, L (2011) Beyond the School Gates: Can Full Service and Extended Schools Overcome Disadvantage? London: Routlege.

Edwards, A (2002) Responsible Research: Ways of Being a Researcher. British Educational Research Journal 28(2):157 - 168.

Edwards, A and Stamou, E (2017) "Relational Approaches to Knowledge Exchange in Social Science Research. ." in Working Relationally in and across Practices, edited by Edwards, A. Cambridge: Cambridge University Press. 
Edwards, T (2000) 'All the Evidence Shows ...': Reasonable Expectations of Educational Research. Oxford Review of Education 26(3 \& 4): 299 - 311.

Fielding, M (2003) The Impact of Impact. Cambridge Journal of Education 33(2):289-295.

Fine, M, Ayala, J and Zaal, M (2012) Public Science and Participatory Policy Development: Reclaiming Policy as a Democratic Project. Journal of Education Policy 27(5):685-692. doi: 10.1080/02680939.2012.710023.

Francis, B (2011) Increasing Impact? An Analysis of Issues Raised by the Impact Agenda in Educational Research. Scottish Educational Review 43(2):4-16.

Gardner, J (2011) Educational Research: What (a) to Do About Impact! British Educational Research Journal 37(4):543-561.

Giroux, H (2002) Neoliberalism, Corporate Culture, and the Promise of Higher Education: The University as a Democratic Public Sphere. Harvard Educational Review 72(4):425-464.

Glenna, L, Shortall, S and Brandl, B (2015) Neoliberalism, the University, Public Goods and Agricultural Innovation. Sociologia Ruralis 55(4):438-459.

Goddard, J (2009) Reinventing the Civic University. London: Nests.

Goddard, J and Vallance, P (2011) The Civic University and the Leadership of Place. Centre for Urban and Regional Development Studies (CURDS) Newcastle University UK.

Goddard, J, Kempton, L, Vallance, P, Cappello, R, Olechnicka, A and Gorzelak, G (2012) The Civic University: Connecting the Global and the Local. Universities, cities and regions loci for knowledge and innovation creation, Londres: Routledge:43-63.

Goddard, J, Hazelkorn, E, Kempton, L and Vallance, P, ed ^eds (2016) The Civic University. The Policy and Leadership Challenges. Cheltenham: Edward Elgar.

Greenhalgh, T and Fahy, N (2015) Research Impact in the Community-Based Health Sciences: An Analysis of 162 Case Studies from the 2014 Uk Research Excellence Framework. BMC medicine 13(1):1.

Hall, E, Leat, D, Wall, K, Higgins, S and Edwards, G (2006) Learning to Learn: Teacher Research in the Zone of Proximal Development. Teacher Development 10(2):149-166.

HEFCE (2012) Assessment Framework and Guidance on Submissions (Updated to Include Addendum

Published in January 2012). Bristol: HEFCE.

HEFCE (2015) Research Excellence Framework 2014: Overview Report by Main Panel C and Sub-Panels 16 to 26. HEFCE: London.

Hillage, J, Pearson, R, Anderson, A and Tamkin, P (1998)"Excellence in Research in Schools Research Report 74." London: Department for Education and Employment.

Khazragui, $\mathrm{H}$ and Hudson, J (2015) Measuring the Benefits of University Research: Impact and the Ref in the Uk. Research Evaluation 24(1):51-62.

King's College London and Digital Science (2015) The Nature, Scale and Beneficiaries of Research Impact: An Initial Analysis of Research Excellence Framework (Ref) 2014 Impact Case Studies. Research Report 2015/01, King's College London and Digital Science, March 2015.

Knowles, C and Burrows, R (2014) The Impact of Impact. Etnográfica. Revista do Centro em Rede de Investigação em Antropologia 18(2)):237-254.

Lubienski, C, Scott, J and DeBray, E (2014) The Politics of Research Production, Promotion, and Utilization in Educational Policy. Educational Policy 28(2):131-144.

Marcella, R, Lockerbie, H and Bloice, L (2016) Beyond Ref 2014: The Impact of Impact Assessment on the Future of Information Research. Journal of information science:0165551516636291. 
Mazzoli Smith, L and Todd, L (2016) Poverty Proofing the School Day: Evaluation and Development Report. Newcastle: Newcastle University.

Mills, D and Ratcliffe, R (2012) After Method? Ethnography in the Knowledge Economy. Qualitative Research 12(2):147-164.

Mortimore, P (2000) Does Educational Research Matter? British Educational Research Journal 26(1):5 - 24.

Mudge, SL (2008) What Is Neo-Liberalism? Socio-Economic Review 6(4):703-731.

Oancea, A (2013a) Interpretations of Research Impact in Seven Disciplines. European Educational Research Journal 12(2):242-250.

Oancea, A (2013b) Buzzwords and Values: The Prominence of "Impact" in Uk Research Policy and Governance, Research Trends 33, https://www.researchtrends.com/Issue33-June-2013/Buzzwords-and-Values/.

Oancea, A (2014) Research Assessment as Governance Technology in the United Kingdom: Findings from a Survey of Rae 2008 Impacts. Zeitschrift für Erziehungswissenschaft 17(6):83-110.

Ovseiko, PV, Oancea, A and Buchan, AM (2012) Assessing Research Impact in Academic Clinical Medicine: A Study Using Research Excellence Framework Pilot Impact Indicators. BMC health services research 12(1):1.

Owen, R, Macnaghten, P and Stilgoe, J (2012) Responsible Research and Innovation: From Science in Society to Science for Society, with Society. Science and Public Policy 39(6):751-760.

Parker, J and Van Teijlingen, E (2012) The Research Excellence Framework (Ref): Assessing the Impact of Social Work Research on Society. Practice 24(1):41-52.

Research Excellence Framework (2014) Research Excellence Framework 2014: Overview Report by Main Panel C and Sub-Panels 16 to 26. Accessed on 4th June 2017 From: http://www.ref.ac.uk/Panels/Paneloverviewreports/.

Rowlands, J and Rawolle, S (2013) Neoliberalism Is Not a Theory of Everything: A Bourdieuian Analysis of Illusio in Educational Research. Critical Studies in Education 54(3):260-272.

Shore, C (2010) Beyond the Multiversity: Neoliberalism and the Rise of the Schizophrenic University. Social Anthropology 18(1):15-29.

Shortt, NK, Pearce, J, Mitchell, R and Smith, KE (2016) Taking Health Geography out of the Academy: Measuring Academic Impact. Social Science \& Medicine 168:265-272.

Shucksmith, M (2016) Interactions: How Can Academics and the Third Sector Work Together to Influence Policy and Practice? Professor Mark Shucksmith Obe, Carnegie Fellow. http://www.carnegieuktrust.org.uk/Carnegieuktrust/WpContent/Uploads/Sites/64/2016/04/Low-Res-2578-Carnegie-Interaction.Pdf. Carnegie UK Trust.

Smith, KE and Stewart, E (2016) We Need to Talk About Impact: Why Social Policy Academics Need to Engage with the Uk's Research Impact Agenda. Journal of Social Policy 46(1):109-127.

Weiss, CH (1977) Research for Policy's Sake: The Enlightenment Function of Social Research. Policy analysis:531-545. 


\begin{tabular}{|l|}
\hline Institution: Newcastle University \\
\hline Unit of Assessment: 25 Education \\
\hline Title of case study: Developing the role of extended schools \\
\hline 1. Summary of the impact \\
\hline
\end{tabular}

Extended schools research and related projects have contributed to debate and policy-making in the UK and in countries in Europe, Asia and Australasia post-2008 on the role of the school in relation to disadvantage. Our research has strongly informed English government policy 2008-11 and the actions (including funding and scaling up extended schools) taken to develop communityoriented, full-service and extended schools to help address the impact of disadvantage on educational outcomes. We have had sustained and far-reaching impact on the policy and actions of schools and local authorities (LAs) in their development of extended schools. Professional practice changes include greater willingness to collaborate across agencies and an amendment to policy on 'raising aspirations' to become 'reaching aspirations'. Additionally our innovative research methodology, a version of theory of change, has been taken up and used by schools, LAs and other organisations.

\section{Underpinning research}

The research focused on how schools (named variously as extended or full-service schools), can contribute to overcoming the effects of disadvantage through partnership with other agencies and institutions. Extended schools have broad aims, beyond a narrow focus on educational attainment, that include the well-being of children, families and indeed the community. These aims are reflected in a wider range of services for students, families and the community offered from the school. The research has involved projects funded by DfE, Joseph Rowntree Foundation (JRF) and local authorities (LAs) totalling $£ 1 \mathrm{~m}$ since 1996, with outputs since 1998. Since 2005 Professor Liz Todd (1995-present) and Colleen Cummings (Research Associate RA, 2000-2011) in Newcastle have been joined by Karen Laing (RA, 2009-present) and Lucy Tiplady (RA, 2005present), and have continued to collaborate with Professor Alan Dyson (1988-2005, thereafter at University of Manchester) and colleagues at University of Manchester. Our research has investigated the processes and outcomes of extended schools from their initial development to the present day.

Our local authority evaluation of efforts to raise the attainment of schools in a disadvantaged area of Newcastle in 1996 drew attention to the needs of economically disadvantaged parents and the role schools could play (1). Our next JRF-funded study, an investigation of the contribution of schools to area regeneration (2000-03), found that at this time schools were generally educating disadvantaged children to enable them to leave the area. Our subsequent research played a key role in a change to this aim, refocusing the role of schools towards the whole community. Two early DfES-funded extended school projects (the demonstration project, 2002-2005, and the pathfinder project, 2002-04) showed how schools were starting to re-focus their role (2). There was evidence that involvement in extended activities could have a positive impact on the cultures of schools and their communities and that it was compatible with raising students' attainment.

The three-year DfES-funded National Evaluation of Full-service Extended Schools (2004-07) developed the innovative mixed methods approach to theory of change methodology (5). This project (4) found evidence that, whilst average impact on educational attainment was not demonstrated, there was some evidence that extended schools 'closed the gap' for disadvantaged children, were highly cost effective, and generated clear and important benefits for individual vulnerable young people's attainment and well-being, for the well-being of vulnerable families and positive changes in schools. This was the first research to generate such results in this manner. The theory of change methodology provided a way to evaluate the complex effects of a multistrand initiative and enabled the impacts to be demonstrated (5). Our reports from the National Evaluation of Extended Services ( $5511 \mathrm{k}$ with University of Manchester, 2009-14) outlined a range of models of the strategic response of schools and local authorities to disadvantage. The Extended Services Subsidy Pathfinder Evaluation, (2008-10) found a range of effective responses of schools to make extra-curricular opportunities available to disadvantaged young people. Our JRF review (2010-11) of research of interventions in aspirations and attitudes (2010-12) found no evidence to support the focus of many extended schools and services on the 'raising of aspirations' (6). Finally, our evaluation of the pupil premium (2012-13) has found that many schools continue to fund activities that reflect a broad focus on the wellbeing of students and families. This focus was part of 
the goal of schools to reduce the impact of economic disadvantage on pupils and existed despite the lack of government policy recommending extended services.

The overall contribution of the research is that we have demonstrated the effects of extended school provisions on children and families, and clarified the facilitating and inhibiting factors in developing extended schools (such as achieving, rather than raising aspirations). We found that strategic partnerships were central to key aspects of extended schools, in particular multi-agency working, involving parents and collaborating with young people. Our findings have focused attention on rethinking the role of the school in relation to disadvantage. Additionally, we developed an appropriate and innovative partnership-based evaluation methodology using a form of theory of change approach.

The work of Todd, Dyson, Cummings and Laing has been truly one of the co-production of ideas and methods. Professor Todd has been PI on all projects since 2002 and funding on joint projects has been shared equally between Newcastle and Manchester. Authorship is always in alphabetical order, reflecting co-production, and separate contributions since 2005 can be identified to the Newcastle team. Professor Todd has made a particular contribution to an understanding of partnerships in extended schools, those of parent partnership, multi-agency working and child participation $(\mathbf{1}, \mathbf{3})$.

\section{References to the research}

1) Todd, E.S. and Higgins, S. (1998) Powerlessness in professional and parent relationships. British Journal of Sociology of Education, 19, 2, 227-236. DOI:10.1080/0142569980190205

2) Cummings, C., Dyson, A. and Todd, L. (2007) Towards extended schools? How education and other professionals understand community-oriented schooling. Children and Society, 21, 189-200. DOI:10.1111/j.1099-0860.2006.00043.x

3) Todd, L. (2007) Partnerships for Inclusive Education. A critical approach to collaborative working. London: Routledge. ISBN 0-415-29845-8. Available from HEI on request. Shortlisted (in top 4) for the NASEN/ TES Academic Book Prize.

4) Cummings, C., Dyson, A. and Todd, L. (2011) Beyond the school gates: Can full service and extended schools overcome disadvantage? Routledge. Prize-winner, highly commended by the Society of Educational Studies, November 2012. REF2 output: 156363.

5) Dyson, A. and Todd, L. (2010) Dealing with complexity: Theory of change evaluation and the full service extended schools initiative. International Journal of Research and Method in Education, 33, 2, 119-134. REF2 output: 154856.

6) Cummings C, Laing K, Law J, McLaughlin J, Papps I, Todd L, Woolner P. (2012) Can changing aspirations and attitudes impact on educational attainment? A review of interventions. York: Joseph Rowntree Foundation. Available at: http://bit.ly/JrJrCX.

\begin{tabular}{|l|l|l|l|l|}
\hline Investigators & Grant Title & Sponsor & Dates & Value \\
\hline $\begin{array}{l}\text { Easen (PI), } \\
\text { Higgins \& Todd }\end{array}$ & $\begin{array}{l}\text { The Educational Achievement } \\
\text { Strategy evaluation }\end{array}$ & $\begin{array}{l}\text { Newcastle Upon Tyne } \\
\text { Local Education } \\
\text { Authority }\end{array}$ & $\begin{array}{l}\text { Mar to Jul } \\
1996\end{array}$ & $£ 5000$ \\
\hline $\begin{array}{l}\text { Dyson (PI), } \\
\text { Milward \& } \\
\text { Cummings }\end{array}$ & $\begin{array}{l}\text { How schools can contribute to } \\
\text { area regeneration }\end{array}$ & $\begin{array}{l}\text { Joseph Rowntree } \\
\text { Foundation (JRF) }\end{array}$ & $2000-03$ & $£ 30,000$ \\
\hline $\begin{array}{l}\text { Todd (Co-PI) \& } \\
\text { Dyson (Co-PI) }\end{array}$ & $\begin{array}{l}\text { Evaluation of the Extended } \\
\text { Schools Pathfinder Project }\end{array}$ & $\begin{array}{l}\text { Department for } \\
\text { Education \& Skills (DfES) }\end{array}$ & $\begin{array}{l}\text { Dec } 2002 \text { to } \\
\text { Jan } 2004\end{array}$ & $£ 66,278$ \\
\hline $\begin{array}{l}\text { Todd (PI) \& } \\
\text { Cummings }\end{array}$ & $\begin{array}{l}\text { Evaluation of the Extended } \\
\text { Schools Demonstration Project }\end{array}$ & DfES & $\begin{array}{l}\text { Feb 2002 to } \\
\text { May 2005 }\end{array}$ & $£ 27,585$ \\
\hline $\begin{array}{l}\text { Todd (PI) \& } \\
\text { Cummings }\end{array}$ & $\begin{array}{l}\text { Evaluation of Full Service } \\
\text { Schools }\end{array}$ & DfES & $\begin{array}{l}\text { Jan } 2004 \text { to } \\
\text { Sep 2007 }\end{array}$ & $£ 219,262$ \\
\hline $\begin{array}{l}\text { Todd (PI) \& } \\
\text { Cummings }\end{array}$ & $\begin{array}{l}\text { Extended Schools Subsidy } \\
\text { Pathfinders Evaluation }\end{array}$ & $\begin{array}{l}\text { Department for Children, } \\
\text { Families and Schools } \\
\text { (DCfS) }\end{array}$ & $\begin{array}{l}\text { Jul 2008 to } \\
\text { Sep 2010 }\end{array}$ & $£ 94,163$ \\
\hline $\begin{array}{l}\text { Todd (PI), } \\
\text { Cummings \& } \\
\text { Laing }\end{array}$ & $\begin{array}{l}\text { National Evaluation of } \\
\text { Extended Services }\end{array}$ & DCfS & $\begin{array}{l}\text { Feb 2009 to } \\
\text { Mar 2012 }\end{array}$ & $£ 403,081$ \\
\hline
\end{tabular}




\begin{tabular}{|c|c|c|c|c|}
\hline $\begin{array}{l}\text { Todd (PI), } \\
\text { Cummings, } \\
\text { Laing, Law, } \\
\text { Papps \& } \\
\text { Woolner }\end{array}$ & $\begin{array}{l}\text { A review of research of } \\
\text { interventions in aspirations } \\
\text { and attitudes: influencing } \\
\text { educational attainment }\end{array}$ & JRF & $\begin{array}{l}\text { Oct } 2010 \text { to } \\
\text { Nov } 2011\end{array}$ & $£ 39,985$ \\
\hline $\begin{array}{l}\text { Todd }(\mathrm{PI}) \& \\
\text { Laing }\end{array}$ & Evaluation of Pupil Premium & $\begin{array}{l}\text { Department for } \\
\text { Education }\end{array}$ & $\begin{array}{l}\text { July 2012- } \\
\text { March } 2013\end{array}$ & $£ 32,580$ \\
\hline
\end{tabular}

\section{Details of the impact}

This research has had longstanding influence on policy and practice in the UK, on government, schools, charities and local authorities (LAs) and international influence on policy and practice in some areas of Europe, Asia and Australasia. In England, according to evidence from the DfE, the research formed a 'major part of the evidence base for policy development' in the Department for Education's children's services delivery mechanisms over the decade that included 2008-11 (senior research officer DfE) (IMP1). Our research informed (in 2008) a move in national policy from having one extended school in each LA area to focusing attention on the availability of extended services in every school and locality. It provided evidence for scaling up the policy, defining the expanding elements of the extended services model, and led to the decision to make funding available to schools post-2010. A senior research officer at the DfE explained the impact on school funding: 'funding was made available (by the DfE) to schools from 2010 onwards (a subsidy pathfinder) to help them provide a wide range of activities for children and young people who were disadvantaged by economic circumstances, and children in care', and that our research 'supported the expansion of the (DfE) policy to help address a wide set of social goals rather than just the educational attainment aims which were the initial focus' (IMP1). Our work also provided the government 'key pieces of evidence to inform spending reviews and policy development' (IMP1). The same DfE testimonial indicates that our research has had influence on recent government policy, that it provided evidence to 'inform the recent publication of More Affordable Childcare (2013)' setting out the Government's plans to increase the amount of affordable provision (IMP1). In addition, the recent development by Save the Children Fund of three 'Children's Zones' pilots in England are based directly on our research.

Pathways to impact have varied. From 2008-10 the DfE reported the Newcastle research findings to practitioners and policy makers via its website. When in 2010 decision-making about extended services was devolved to schools, the DfE commissioned from the Newcastle-Manchester team a manual for head teachers based on all our previous research in this area. Our distinctive partnership research design enabled schools and LAs to reflect on and apply our research. Our four day-conferences since June 2012 on extended services have been well attended (each 40+) and valued (evaluation form comments): 'the opportunity to do things differently'; and 'raise awareness within the services of the importance of children's zones aims and encouraging multiagency work'. Todd and Dyson have accepted invitations to present to large practitioner and policy-maker audiences (from 50 to 500 people). For Todd this has included countries in Europe (UK, Spain, Sweden and Netherlands), Asia (Vietnam) and Australasia (New Zealand and Fiji).

Our impact on schools, LAs, and partner organisations is demonstrated by repeated references to our research in policy documents (i.e., Northern Ireland Assembly (IMP2), Hotspur Primary School in Newcastle (IMP3), Solihul LA, W. Sussex LA, ContinYou) and that we were engaged to conduct local evaluations of extended services provisions for seven English LAs, from Northumberland to Wiltshire, and to edit, from 2007-11, a national practitioner publication on extended schools for teachers, the 'Extended Schools Update' (circulation in 2010: 456 schools/LAs) (IMP4). This publication informed and stimulated the actions and policies of extended schools and local authorities and contains many examples of the impact of Newcastle's research (IMP4). A director of extended services in one LA noted our research had: 'played a significant part in helping the schools in the (...) area to: develop policy and practice in 'Extended Services'... [and to...] stimulate and inform our direction of travel'. We are quoted as being responsible for their nomination as a Children Zones pilot. The manager of Rural Youth Offending Service demonstrated how our research evidence was used in 2013 to bid successfully for further funding. Our theory of change methodology has been taken up by schools, LAs and other organisations to research organisational change. The impact of this approach is evidenced by comments from 
senior education managers in Durham, North Tyneside, and Manchester (IMP5). The specialist educational psychologist in Durham said: 'this model ... seemed to offer a way of navigating through the (sometimes messy) complexities of researching organisational development, and giving validity to observed changes at a number of levels (student, staff, systems etc). I was also interested in the process of theory building'. Impact on schools is evidenced by a deputy head of a primary school in Manchester, who said: 'We've used your change document... it's helped us to ensure the impact of things in a way that we hadn't thought of' (research interview quote) (IMP5).

There has been a cultural shift as a result of our research. It has influenced government thinking, inhibiting the policy of 'raising aspirations'. This was a key aim of many extended schools; but the research found no evidence of its utility, instead showing that a better focus was sustaining aspiration. The finding has been communicated through invitations to speak at well-attended practitioner, manager and policy-maker conferences (2011-13) organised by the DfE, various English councils and the Bevan Foundation (Wales). JRF representatives took the research to the UK Cabinet Office where it has influenced thinking about pupil premiums, and Todd was invited to discuss the research with the Minister for Education in Wales. In February 2013, Michael Gove referenced a statistic which was based in part on our review, in a speech to the Social Market Foundation (IMP6). Practices of professionals have changed as workers in city councils (i.e. Newcastle, North Tyneside, Northumberland and Oxford) recognise the need to change their language. For example, 'Children North East' consulted us on the changed wording of their mission statement to remove the words 'raising aspirations' (IMP7): 'We now see our charitable purpose to create opportunities for children and young people to realise their aspirations' (Chief Executive, Children North East) (IMP7). 'Many Local Authorities in the NE are currently reviewing their child poverty documents and we expect that language surrounding aspirations (in many North East LAs) to be markedly different as a result of the research findings' (Regional Child Poverty Research and Action Plan Co-ordinator). The research is cited as evidence in the Education Endowment Fund toolkit against adopting interventions that focus on raising aspirations.

Internationally our research has informed debate and policy-making. The Cabinet Leader of the borough of Amsterdam West, refers to decision-making that increased the out of school hours opportunities for disadvantaged young people, and asserts: 'To me a policy maker from West Amsterdam, (Todd's) research offers great opportunities for discussion between policy makers from the local government and the school board representatives, because of its 'hands-on' character' (IMP8). An NGO in Vietnam attributes its current success partly to our research, according to its director: 'We are now leading in renovation of the mental health care system in Vietnam ... pioneer in ...courses on social work...related to women and children...Contribution on this change, certainly has come from your work and our collaboration' (IMP9). Our research is extensively quoted by the Foundation for Young Australians in their literature review for National Collaboration Project: Extended Service School Model (IMP10). Our outputs have influenced teachers in other locations nationally (Glasgow and Belfast) and internationally (Iceland, Sweden, New Zealand).

\section{Sources to corroborate the impact}

(IMP1) Testimonial statement: senior research officer DfE, July 2013.

(IMP2) Northern Ireland Assembly briefing paper 03/11, November 2010, accessed from http://www.niassembly.gov.uk/researchandlibrary/2011/0311.pdf.

(IMP3) 'Hotspur Primary School. Review and development of extended services provision' by Alison Priestley and Malcolm Stone, 2012. And Hotspur Proposal for extended school provision.

(IMP4) Scanned example edition of professional journal 'Extended Schools Update'.

(IMP5) Research Interview data: Deputy Head, at a primary school in Manchester, 2013.

(IMP6) Testimonial email: JRF Programme Manager, 2 Sept 2013.

(IMP7) Testimonial letter: Chief Executive at Children North East, 11 July 2013 \& Blog Children North East 20 Sept 2012

(IMP8) Testimonial letter: Cabinet Leader of the Borough of Amsterdam W.Netherlands, 16.7.12.

(IMP9) Testimonial email from Director Research and Training Center for Community Development (RTCCD), Hanoi, Vietnam, 20 July 2013.

(IMP10) Foundation for Young Australians. Literature review for 'National Collaboration Project: Extended Service School Model', dated 2010, Accessed from: http://bit.ly/qSHZkp. 